\title{
上壁を有する衝突喷流熱伝達の特性に関する基礎研究*
}

(3-スリット・ノズルの場合の数值予測)

\author{
一 宮 浩 市*1, 保 坂 宣 夫*2
}

\author{
A Fundamental Study of Heat Transfer Characteristics \\ Due to Confined Impinging Two-Dimensional Jets \\ (Numerical Estimation for Three Laminar Slot Jets)
}

\author{
Koichi ICHIMIYA and Nobuo HOSAKA
}

\begin{abstract}
The present study describes the numerical analysis of the characteristics of the flow situation and impingement heat transfer caused by three laminar slot jets. Numerical values were obtained for the dimensionless space $H=0.5-6$, the dimensionless pitch $P=4-16$ and the Reynolds number $R e=100$ 1000 . It was found that a recirculating flow is generated between two nozzles and position of the maximum heat transfer depends on the flow from the next nozzle and the space between the nozzle and the impinging surface. The array of the nozzles effectively enhances the local heat transfer and keeps it at a high level.
\end{abstract}

Key Words: Thermal Engineering, Impinging Flow, Impingement Heat Transfer, Array of Nozzles, Forced Convection, Numerical Analysis

\section{1. 粕}

衝突噴流は, 局所熱伝達の増大, 除熱促進, 物体の 乾燥などの目的のために実用的にも幅広く応用されて いる，著者の一人も，高温鋼片の温度の均一化に関連 して, 衝突噴流による鋼片上の熱伝達 ${ }^{(1)}$, 鋼片内の非 定常熱伝導 ${ }^{(2)}$, および乱流噴流による衝突噴流熱伝達 の特性 (3)などを検討してきた。これらは単一のスリッ ト・ノズルに対する数值解析および実験的検討であっ た。しかし実用性を考虑した場合，必ずしも単一ノス ルのみならず複数ノズルに対する検討も必要となる。 従来, 複数ノズルによる研究では, 比較的ノズル・衝突 面間距離の大きい，しかも高い出ロレイノルズ数で実 験が行われている(4)(5). しかし解析的に検討されたも のはあまり見られない，したがって著者らは複数ノズ ルの最も基礎的で，数值計算の簡素化も考慮し，しか も他の複数ノズルの場合の伝熱流動状態もある程度推 測可能と思われる3ースリット・ノズルに注目した。 本研究では, 複数ノズルの中で 3 個のスリット形ノ

*平成 2 年3月 10 日 中国四国支部第 28 期総会講演会にお いて雃演, 原稿受付 平成元年 4 月 27 日.

*1 正員, 山梨大学工学部（ 8400 甲付市武田 4-3-11)。

*2 正員, (侏)本田技術研究所 ( $8321-33$ 栃木県苊賀郡芳贺町大 字下高根沢 4630).
ズルより層流状態で噴出した流体が，平滑加熱面に衝 突した場合，その局所伝熱流動がいかなる特性を示す かをレイノルズ数，ノズル・衝突面間距離，ノスルピッ チを変化させて数值的に解析し，単一ノズルの場合と の比較および応用的検討を行うものである.

$$
\text { 主な鱾号 }
$$

$$
\begin{aligned}
d & : \text { ノズル幅の半分 } \\
h_{2} & : \text { ノズ・衝突面間距離 } \\
H & : \text { ノ゙ル・衝突面間無次元距離 }=h_{2} / d \\
l_{2} & : \text { 流路出口までの距離 } \\
N u & : \text { ヌセルト数 }=\alpha \cdot 2 d / \lambda \\
p & : \text { ノズル間ピッチ } \\
P & : \text { ノスル間無次元ピッチ = }=p / d \\
\operatorname{Pr} & : \text { プラントル数 } \\
q & : \text { 熱流束 } \\
\operatorname{Re} & : \text { レイノルズ数 }=v_{o} \cdot 2 d / \nu \\
\operatorname{Re} e_{2} & : \text { 第 } 2 \text { ノズのレイノルズ数 } \\
T & : \text { 温度 } \\
T_{o} & : \text { ノズル出口の流体温度 } \\
u & : x \text { 方向速度 } \\
U & : x \text { 方向無次元速度 }=u / v_{o} \\
v & : y \text { 方向速度 }
\end{aligned}
$$




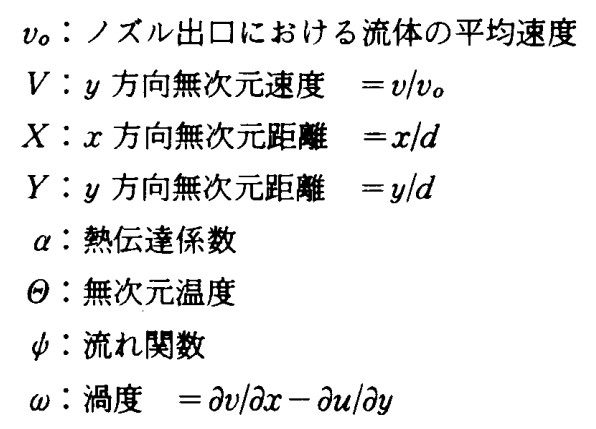

\section{2. 间题の設定}

本研究では，鋼板、フィルム等といった比較的広い 物体からの除熱促進, 熱伝達の改善等を対象として, その物体に複数ノズル（本研究では 3 -スリット・ノス ル）より噴出した流体が衝突した場合，その流動状態 および局所熱伝達の変化を数值的に予測するものであ る.また,ノズルと同じレベルに壁を設けた系が,より 実用に近く，それを断熱壁として検討する。

基礎座標系を図 1 に示す。対象とする物体表面とし ては一様加熱された平滑伝熱面で同時に衝乫面とな る.この平滑加熱面にノズル幅 $2 d$ のスリット・ノズル (二次元)上り温度 $T_{o}$ の流体が噴出し衝突する，3-ス リット・ノズルのうち中央のノズルの中心が対称軸と なり，他のノズル間のピッチはрとする，中央ノズル より，非圧縮性粘性流体が発達した層流分布で噴出し 左右に流動方向を変化し, 途中, 他のノズルょり噴出 した流体と併合して流路出口に至る. 解析に際しては, 伝熱・流動状態は定常でるく射熱は無視する。以後, 中 央ノズルに榉接したノズルを第 2 ノズルと呼ぶことに する。

\section{3. 基礎式と数优解法}

流動伝熱状態を一般的に評価するために，流れおよ びエネルギー式を無次元化し，流れについては流れ関 数, 渦度を導入し压力項を消去して数値的に計算を行 った。

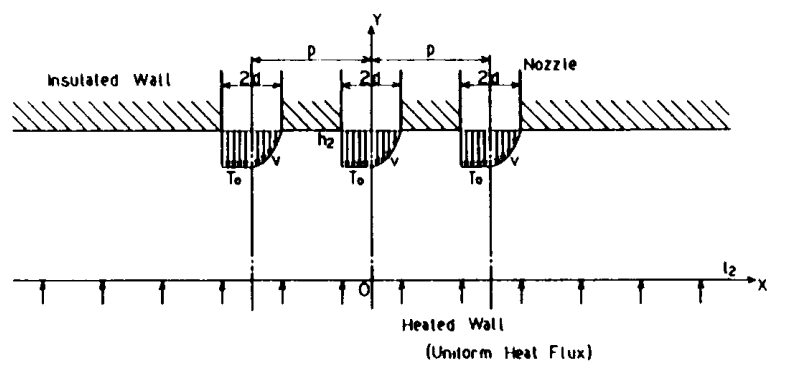

図 1 座標系

$$
\Psi=\frac{\psi}{d v_{o}}, \Omega=\frac{\omega d}{v_{o}}, \Theta=\frac{\lambda\left(T-T_{o}\right)}{q \cdot 2 d}
$$

流れおよびエネルギー式を示すと次式となる，流れ に関する無次元式

$$
\begin{aligned}
& \frac{\partial^{2} \Psi}{\partial X^{2}}+\frac{\partial^{2} \Psi}{\partial Y^{2}}=-\Omega \\
& \frac{\partial \Psi}{\partial Y} \frac{\partial \Omega}{\partial X}-\frac{\partial \Psi}{\partial X} \frac{\partial \Omega}{\partial Y}=\frac{2}{\operatorname{Re}}\left(\frac{\partial^{2} \Omega}{\partial X^{2}}+\frac{\partial^{2} \Omega}{\partial Y^{2}}\right)
\end{aligned}
$$

エネルギーに咸する無次元式

$$
\frac{\partial \Psi}{\partial Y} \frac{\partial \Theta}{\partial X}-\frac{\partial \Psi}{\partial X} \frac{\partial \Theta}{\partial Y}=\frac{2}{\operatorname{RePr}}\left(\frac{\partial^{2} \Theta}{\partial X^{2}}+\frac{\partial^{2} \Theta}{\partial Y^{2}}\right)
$$

流れと温度に関する境界条件も無次元化すると次式と なる。

・ノズル出ロ $\left(0 \leqq X \leqq 1, Y=h_{2} / d\right)$

$$
U=0, V=\frac{3}{2}\left(X^{2}-1\right), \Theta=0
$$

・第 2 ノズル出ロ $\left(P-1 \leqq X \leqq P+1, Y=h_{2} / d\right)$

$$
U=0, V=\frac{3}{2}\left\{(X-P)^{2}-1\right\}, \Theta=0
$$

- 流路上壁 $\left(1 \leqq X \leqq P-1, P+1 \leqq X \leqq l_{2} / d, Y=h_{2} / d\right)$

$$
U=0, V=0, \frac{\partial \Theta}{\partial Y}=0
$$

- 流路下壁 $\left(0 \leqq X \leqq l_{2} / d, Y=0\right)$

$$
U=0, V=0, \frac{\partial \Theta}{\partial Y}=-0.5
$$

- 対称軸 $\left(X=0,0 \leqq Y \leqq h_{2} / d\right)$

$$
U=0, \frac{\partial V}{\partial X}=0, \frac{\partial \Theta}{\partial X}=0
$$

- 流路出口 $\left(X=l_{2} / d, 0 \leqq Y \leqq h_{2} / d\right)$

$$
\frac{\partial U}{\partial X}=0, V=0, \frac{\partial}{\partial X}\left(\frac{\partial \Theta}{\partial X}\right)=0
$$

第 2 ノズルから噴出される流体により流路を流れる 流量が增大する。この流れが中央ノズル（つまり上流 側）方向に逆流し，上流からの流れと干涉する可能性 も考えられたが，煙注入法による流れの可視化 [図 3 （c）参照]で観察した結果，そのような影響は存在し なかった。また第 2 ノズルより下流の, 流量の増大に 伴う境界条件，質量の保存は考虑されている.

平滑加熱面（衝突面）上の局所ヌセルト数は次式で 定義される。

$$
N u=\frac{q \cdot 2 d}{\lambda\left(T_{w}-T_{o}\right)}=\frac{1}{\Theta_{w}}
$$

計算条件としては，ノスル幅の $1 / 2$ を基準長さとし て, $P r=0.7$ に対し無次元ノスルピッチ $P$ を 4.0, $6.0,10.0,16.0$ の 4 種類, ノスルと衝突面間無次元距 離 $H$ を $0.5,1.0,1.5,2.0,3.0,6.0$ の 6 種類，ノズ ル出口のレイノルズ数 Reを 100 から 1000 まで 5 種 
類変化させて行った。

数値計算法としては, 主として Gosman ら ${ }^{(6)} の$ 方法 を用いた。従来，無次元渦度 $\Omega_{j}$ は壁面からの線形分布 を仮定して求められていたが，本計算では，壁面を含 めた 3 点 (図 2 参照) の流れ関数 $\Psi_{j}, \Psi_{j-1}, \Psi_{j-2}$ で表示 した。すなわち、

$$
\Omega_{j}=\frac{7 \Psi_{j}-8 \Psi_{j-1}+\Psi_{j-2}}{2 \Delta Y^{2}}
$$

ただし $\Delta Y$ は格子点間距離である。

また壁面上の温度勾配も 3 点近似を行って精度を向 上させた。

計算手法の概要を示すと，まず基礎式 (2)，(3)， （4）を皘分し，保存形に書き換え，風上差分を適用し て，収束条件を満たすまで反復計算を行うものであ る、対称軸および壁面付近の格子点は階段状に密にな っている. 収束条件は各格子点の $\Psi, \Omega, \Theta$ の逐次近似 の二つの愦差の最大値が次式を満足するとした。

$$
\operatorname{Max}\left|\phi_{p}(n)-\phi_{p}(n-1)\right| \leqq 8 \times 10^{-4}
$$

なお $\phi_{p}$ は, $\Psi, \Omega, \Theta に$ 対応する。

\section{4. 結果およひ検封}

$4 \cdot 1$ 流㔖状贸 複数ノズルおよび単一ノズルに よる流動状態の比較を図 3 に示す。単一ノズルの場合 の無次元流れ関数 [図 3(a)]によると,ノズルより噴 出した流体は加熱面に衝突した後, 流れ方向を $90^{\circ}$ 変 える. その後, 下流になるにつれ流路断面内の最大速 度の位置は衝突面より離れ，ノズル付近の上壁には循 環流が形成される。それに対し，複数ノズル[図 3 (b) ] では，中央ノズルと第 2 ノズル間の上壁付近で, 循環流が形成される。ささに第 2 ノズルより流体が噴 出した直後では, 中央ノズルより噴出した流体による 街突面付近の最高速度と第 2 ノスルより噴出した流体 の上壁付近の最高速度の二つの最高速度が同一断面内 に現れる、第 2 ノズルからの流体は，中央ノズルから の流体が存在するため, 衝乫噴流とはいえ, みかけ上 $H$ が滅少した流路への噴流になり，同じノズル・衝突 面間距離に対しての単一ノズルの場合に比較して上壁

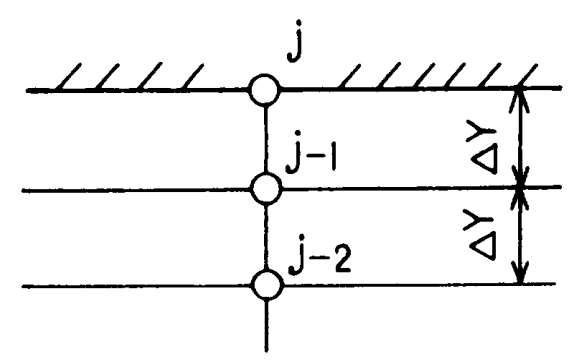

図 2 壁付近の格子点
には循環流が形成されにくくなる，以上の結果を流れ の可視化と対応させたのが図 3 (c) である. 中央ノス ルによる流れが, 第 2 ノズルからの噴流の下側, すな

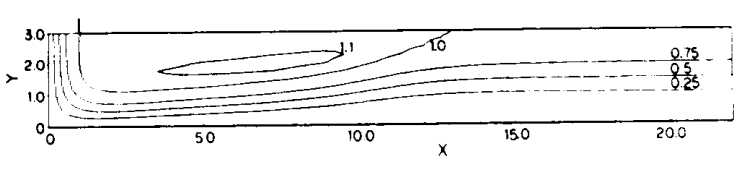

(a) 単-・ ズル $(H=3.0, R e=500)$

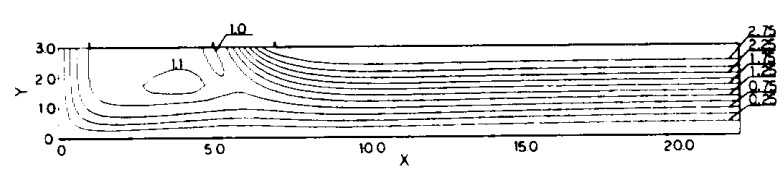

(b) 複数ノスル $(P=6.0, H=3.0, R e=500)$

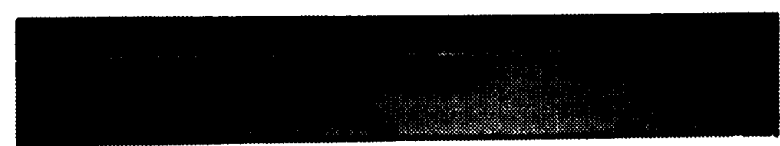

(c) 可視化写真 $(P=6.0, H=3.0, R e=500)$

図 3 流動状態

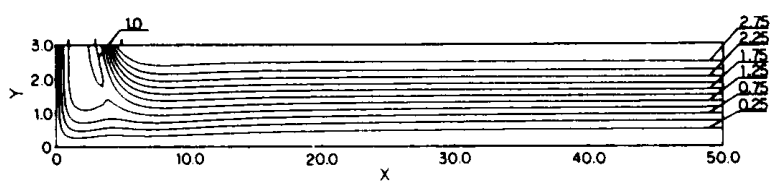

$P=4.0, H=3.0, R e=500$

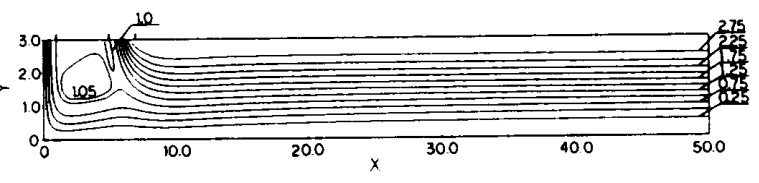

$P=6.0, H=3.0, R e=500$

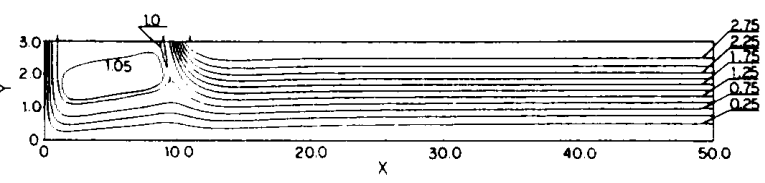

$P=10.0, H=3.0, R_{\ell}=500$

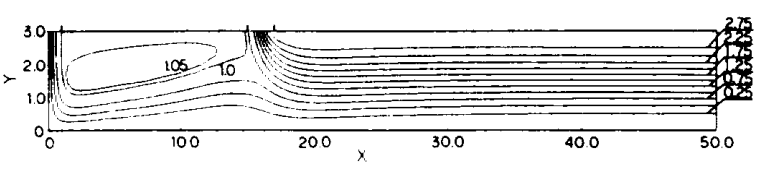

$P=16.0, H=3.0, R e=500$

図 4 無次元流れ間数 $\Psi(P$ の影敏) 
わち加熱面に治って流れ込んでいるのが明白に現れて いる.

図 4 に, 複数ノズルのピッチの, 流れに与える影響 を示す.ノズル・衝突面間無次元距離 $H=3.0, R e=500$ に対し, 無次元ピッチ $P$ を 4 から 16 まで 4 種類変化 させている。一般に, 中央ノズルからの噴出流体は第 2ノズルからの流体の下側へ流れ込む．その流れ込む 位置は, 比較的ピッチの小さい場合, 第 2 ノズル幅内 にあったのが、ピッチの增大につれ，第 2 ノズル幅上 流端に移動する。さらに中央ノズルと第 2 ノズ間に 形成された循環流の領域が拡大している。

図 5 に $P=10, R e=500$ に対するノズル・衝突面間
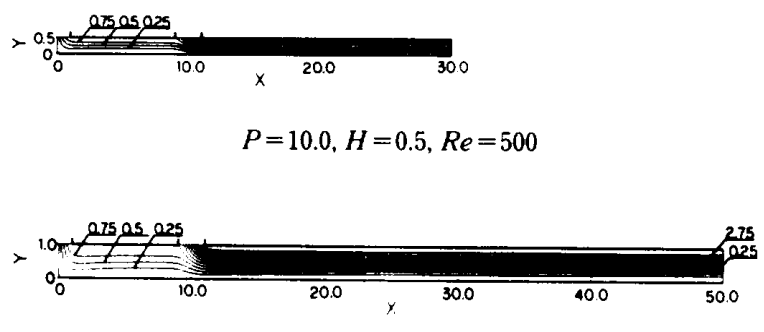

$P=10.0, H=1.0, \operatorname{Re}=500$
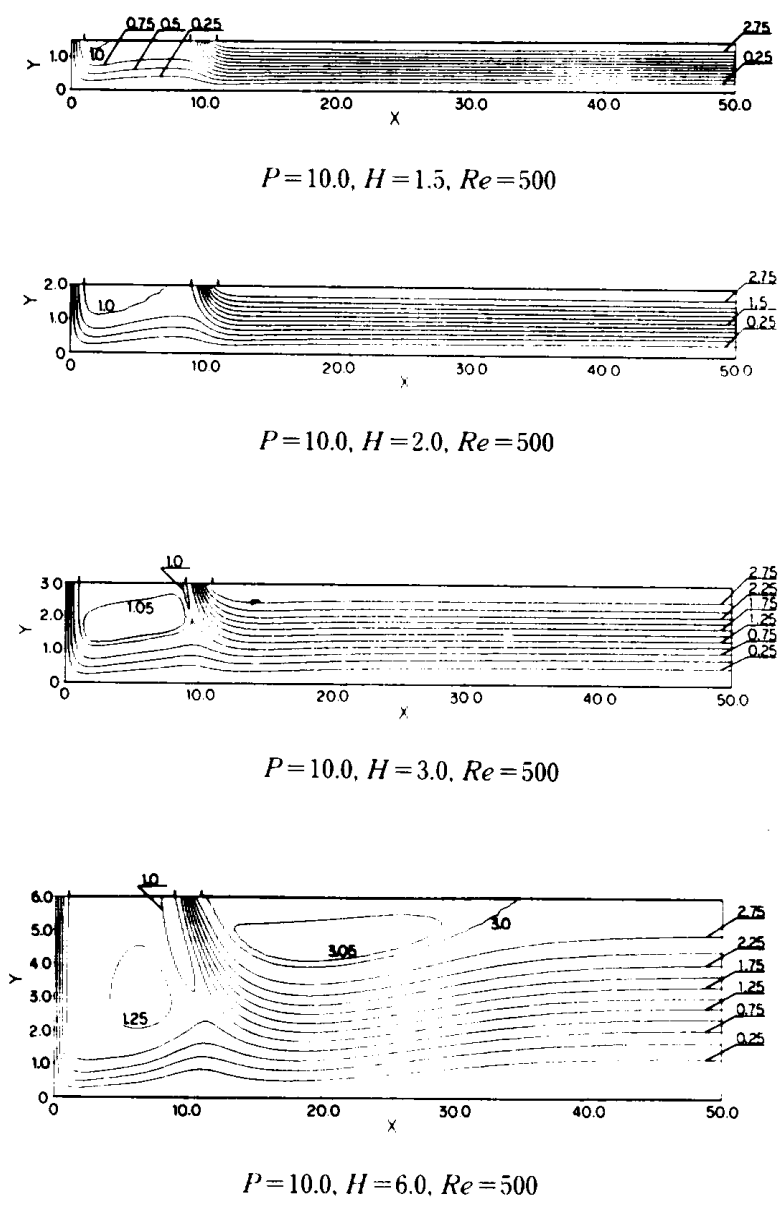

図 5 無次元流九関数 $\Psi(H$ の影都 $)$
無次元距離 $H$ を 0.5 から 6.0 まで 6 種類変化させた 場合の無次元流れ関数の変化を示す. $H$ が 0.5 および 1.0 程度までは衝突噴流による循環流の形成は見られ ないが, $H=1.5$ およ゙ 2.0 で中央ノズル上壁付近に 小循環流の形成がみられる. $H=6.0$ にいたっては， ズル間, および第 2 ノズ上壁面付近に大循環流が現 れる.また, 単一ノズルの場合, 噴出流体が衝突後, 下 流衝突面上に局所熱伝達の減少の原因となる小渦が現 れるが(7), 複数ノズルでは第 2 ノズルからの噴出のた め衝突面上の小渦は形成されない。

図 6 に, $H=3.0, P=10$ に対するノズルレイノルズ 数 $\operatorname{Re}$ の影響を示す. $R e$ が低いと噴流が衙突した後 の流動方向の変化が著しく, Reの影響はノスル間の 循環流の大きさに現れる。しかし，Reが 500 程度以上 になると流れ関数の状態にはそれほど著しい差は現れ ていない.

$4 \cdot 2$ 局所第伝薏 前節で述べた流動状態に対す る局所熱伝達の変化を検討する。

図 7 において, 流路内の流体の温度上昇を単一ノズ ルと複数ノズルで比較する. 単一ノズルの場合, 噴流 が加熱面に衝突後, 下流方向に温度上昇が得られる.
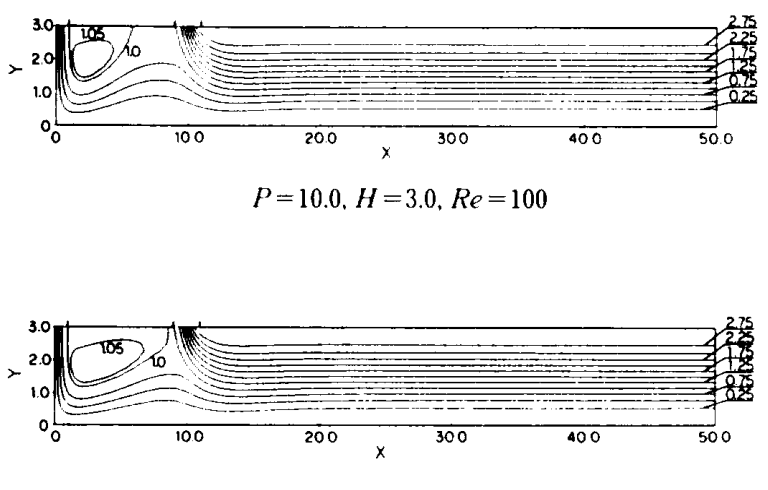

$P=10.0, H=3.0, R e=200$

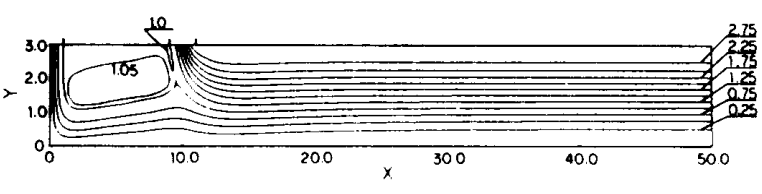

$P=10.0, H=3.0, \operatorname{Re}=500$

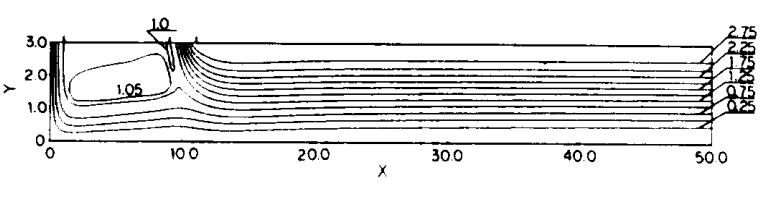

$P=10.0, H=10.0, R e=1000$

図 6 無次元流れ関数 $\Psi(R e$ の影響) 
複数ノズルでは，ノズル間で温度上昇が生じた後，第 2 ノズルより，中央ノズと同じ $T_{o}$ の流体が噴出す るためいったん, 温度が低下した後, 下流に向かって 温度上昇域が増大する。

図 8 に, $H=1.0, R e=800$ に対する無次元ノズルピ ッチの変化が局所ヌセルト数に及ほす影響を両対数関 係で示す。横軸は中央ノズル中心からの流れ方向の無

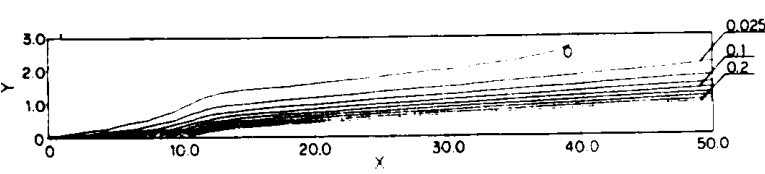

(a) 单.ノズ $(H=3.0, R \ell=500)$

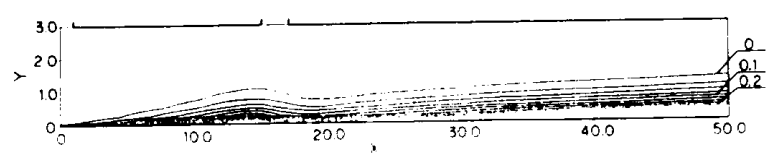

(b) 複数, ス八 $(P=16.0, H=3.0 . R e=500)$

図 7 無次元温度 $\Theta$

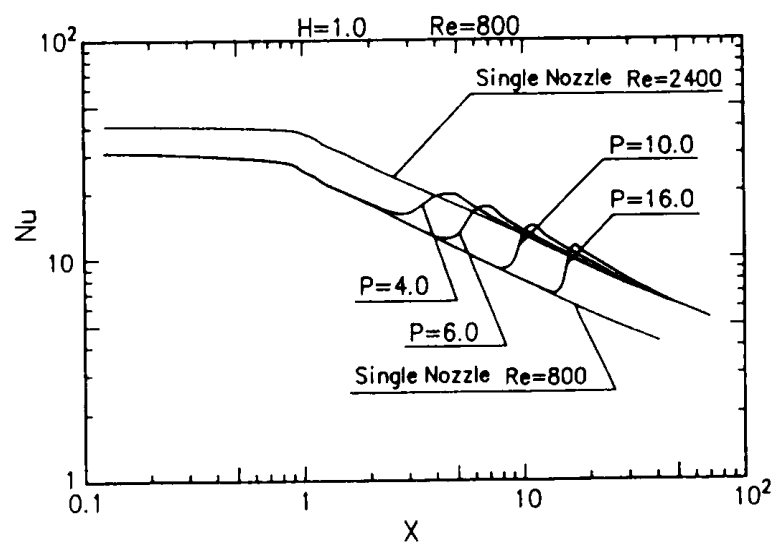

図 8 局所ヌセルト数 $N u(P$ の影䇾 $)$

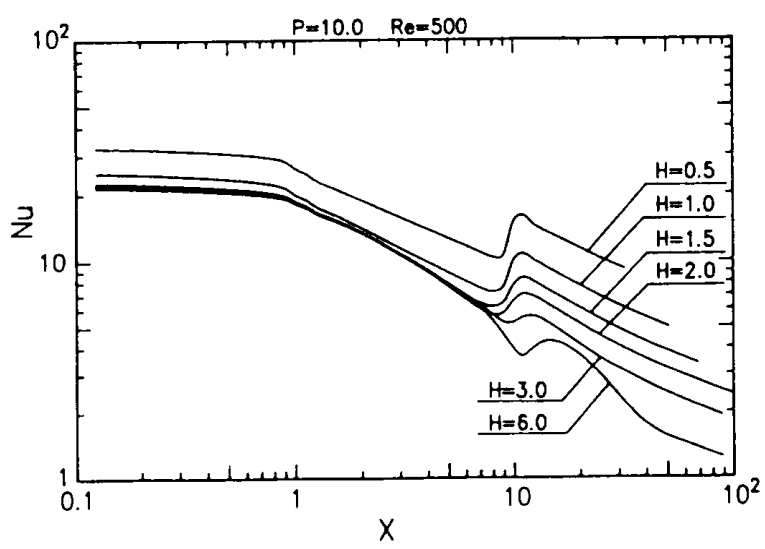

図 9 局所ヌセルト数 $N u$ ( $H$ の影響 $)$
次元距離である. 同時に $R e=800$,および流量が 3 倍 となった $R e=2400$ に対する単一ノスルの衝突噴流 熱伝達の值を破線で示している，局所熱伝達は中央， ズルによる衝突噴流の岐点の熱伝達より下流へ減少 し，第 2 ノズル下わずか上流側より上昇しはじめ，第 2 ノスルより下流側で極大值を取り $R e=2400$ の単 一ノズルによる值に漸近する，熱伝達の上昇には，流 量の増大による熱伝達のレベルの増大と, $R e=2400$ の単一ノズルにより得られる值より大きい部分，すな わち流体の衝突による増大の部分とに分けられる。

図 9 に, $P=10, R e=500$ に対するノズル・衝突面間 無次元距離 $H$ の影響を示す. $H$ の小さいほど, 局所又 セルト数の值は高く,第 2 ノズル前の $N u$ の極小値お よび第 2 ノズル付近の極大值の位置が $H$ の増大につ れて下流に移動している。これは図 5 の無次元流机関 数の挙動と対応し，第 2 ノズルからの流れの下側に， 中央ノズルからの流れが入り込むところで $N u$ が極 大值をとっている．定量的には，第 2 ノズルによる $N u$ の極大值と極小值の比は, $H=0.5$ で約 1.6, $H=$ 6.0 で約 1.2 となり，Hが小さいほど第 2 ノズルの影

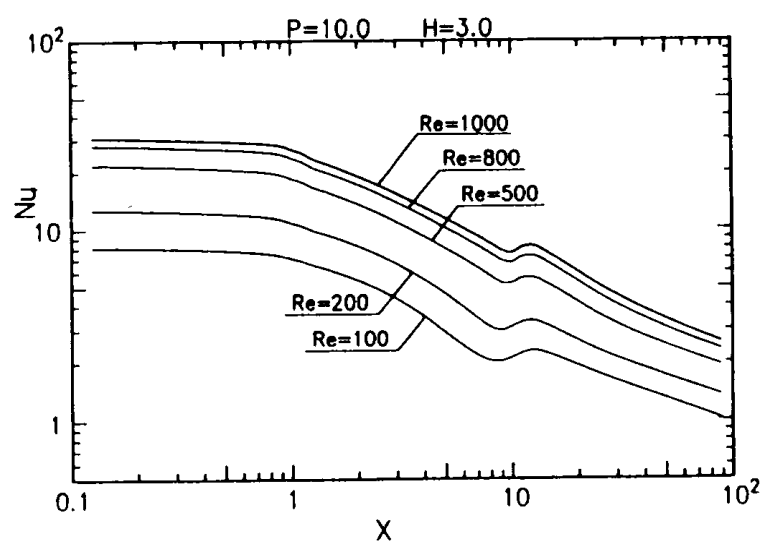

図 10 局所又セルト数 $\mathrm{Nu}(R e$ の影響 $)$

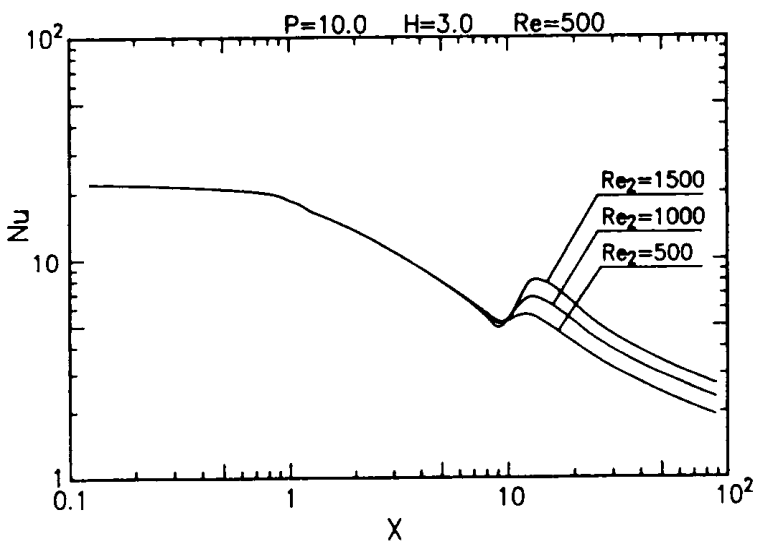

図 11 局所ヌセルト数 $\mathrm{Nu}\left(\operatorname{Re}_{2}\right.$ の影等 $)$ 


\section{響は增大する。}

図 10 に $P=10, H=3.0$ に対し，熱伝達に与える $R e$ の影蠁を示す，Reの増大は熱伝達のレベルを増大さ せるが，第 2 ノズルによる局所ヌセルト数の極大值の 位置はほとんど変化しない，比較的レイノルズ数の低 い場合，第 2 ノスルによる熱伝達の増大開始が相対的 に早くなる。

図 11 に第 2 ノスル出ロにおけるレイノルズ数 $R_{2}$ の局所ヌセルト数に与える影響を示す. 図 8 から図 10 までの結果は中央ノズルおよび第 2 ノズルとも同じ $R e$ の噴流を噴出させた場合であるが，その場合第 2 ノズル下の極大值の位置は変化しない.しかし, $R e_{2}$ が中央ノズルの Reより増大すると熱伝達係数の増加 のみならず，極大值の位置が下流側へ移行し，影警領 域（伝熱促進域）の拡大も得られる.

\section{5. 結}

複数ノズによる衝突德流熱伝達の特性を基礎的に 検討するために，3ースリット・ノスルの層流噴流によ る衝突噴流熱伝達の伝熱流動を数值的に求め，以下の 結果が得られた。

3ースリット・ノズルによる局所熱伝達の増大には， 第 2 ノスルからの噴流の影隌による熱伝達の上昇と，
流量の増大による熱伝達の上昇に分けられる、スリッ ト・ノズルのピッチ，ノズル・衝突面間距離および $R e$ の変化が，ノズル間の循環流の形成および，中央ノズ ルからの流体が第 2 ノズルからの流体の下側に流れ込 む位置に影響を及ほし，それに対応して第 2 ノズルか らの噴流による局所ヌセルト数の極大值の位置が移動 する。

実用的には，物体の熱伝達および温度をどのレベル に維持するかにより，ノズルピッチ，ノズル・衝突面間 距離，レイノルズ数を決定しなければならない，本研 究で行った各種パラメータを変化させた結果は，それ らを决定する際の基礎的资料になり得ると考える.

\section{文献}

（1）一宮・小林・越後，機論，52-474，B(1986)，904.

（2）一宮・小林・越後，機論，52-481，B(1986)，3304

（3）一宮・小林・越後，機詥，53-486，B(1987)，511.

(4) Martin, H., Advanced in Heat Transfer, (1977), 12 Acad. Press.

(5) Gardon, R., and Akfirat, J. C., Trans. ASME, Ser. C. 88-1(1966), 101.

(6) Gosman, A. D., ほ か 4 名, Heat Mass Transfer in Recirculating Flous, (1969), 89, Acad. Press.

(7) Law, H. S., and Masliyah, J. H., Int. J. Heat Mass Transfer, 27-4(1984), 529. 